\title{
Intermédialités
}

Histoire et théorie des arts, des lettres et des techniques

Intermediality

History and Theory of the Arts, Literature and Technologies

\section{Why Intermediality — if at all?}

\section{Hans Ulrich Gumbrecht}

Numéro 2, automne 2003

URI : https://id.erudit.org/iderudit/1005464ar

DOI : https://doi.org/10.7202/1005464ar

Aller au sommaire du numéro

Éditeur(s)

Centre de recherche sur l'intermédialité

ISSN

1705-8546 (imprimé)

1920-3136 (numérique)

Découvrir la revue

Citer cet article

Gumbrecht, H. U. (2003). Why Intermediality — if at all? Intermédialités /

Intermediality, (2), 173-178. https://doi.org/10.7202/1005464ar

\section{Résumé de l'article}

Autant le concept d'intertextualité avait connu un grand succès dans les sciences humaines parce qu'il constituait le parachèvement d'une conception du monde comme lisible, autant l'intermédialité n'aura vraiment de portée que si elle nous permet de sortir de ce modèle et d'ouvrir des problématiques inédites. En reconstruisant à grands traits ces paradigmes conceptuels, il s'agit de savoir comment repenser les médias hors des procédures herméneutiques et du seul univers de la signification.
Ce document est protégé par la loi sur le droit d'auteur. L'utilisation des services d'Érudit (y compris la reproduction) est assujettie à sa politique d'utilisation que vous pouvez consulter en ligne.

https://apropos.erudit.org/fr/usagers/politique-dutilisation/ 


\title{
Why Intermediality - if at all?
}

\author{
HANS ULRICH GUMBRECHT
}

1.

About a quarter of a century ago, the concept of "intertextuality" sounded as intellectually sharp and as promising all over the international world of the humanities as I imagine the word "intermediality" must sound in the ears of German scholars today (for the interest in "media" and "materialities" of communication is much more of a specifically German phenomenon than German colleagues seem to imagine). And what does the shift of fascination from "intertextuality" to "intermediality" indicate? Perhaps we can say that the long vanished enthusiasm for Intertextuality marked the peak and the near end of a time when the paradigm of the "readability of the world" dominated the Humanities without any competition. Regardless of whether they opted, in a more tradition-oriented style, for "hermeneutics" or, with more modernist ambitions, for "semiotics," all scholars in humanities, during the 1970s and 1980s, shared the-hardly ever mentioned-premise that whatever object they would consider worthy of their attention had to be dealt with as a "text." This premise had generated the subsequent expectation that the different parts making up the objects/texts in question referred to each other within the rules of one or the other "grammar," a grammar whose understanding would allow the observer to decipher the very objects/texts in question as surfaces, and that all these surfaces would ultimately yield some meaning. Music or food, behavior or painting, machine or plant-there was nothing, in the heydays of intertextuality, that did not look like a text to us, a text that, based on a grammar, would carry a meaning. At the same time, it was the much cherished utopian dream of the humanists, twenty or thirty years ago, to bring together all these different "types of texts"-music-"texts" and food-"texts," behavior-"texts" and even linguistic 
texts - in some meta-grammar of culture that we somehow imagined to become the equivalent of a cosmology.

\section{2.}

Seen from an historical angle, there was a hidden legacy of intellectual repression behind those humanistic dreams of universal readability and of multiple grammars. The motif of "readability" had first emerged at the dawn of Western modernity, when men abandoned the self-referential idea of inhabiting a cosmos that they had considered to be the work of divine creation and began to think of themselves as the eccentric observers of a world that was an ensemble of material objects. This very shift produced the subject/object-paradigm within

174 which the subject would think of himself (or herself) as a disembodied entity capable of conveying meanings to the objects constituting the world. To the disembodied subject-interpreter of early Modernity, the world of objects must indeed have looked like a book. It was not before the early 19th century that the world-observing and world-interpreting Subject became obsessively self-reflexive; following a proposal by Niklas Luhmann, we can distinguish the early modern Subject as a "first order observer" from a 19th century "second order observer" who was privileged (or condemned) to observe himself or herself in the act of observation. ${ }^{1}$ One of many consequences stemming from the new and seemingly unavoidable habit of self-observation was the re-discovery of the human body and of the human senses as a condition of self-observation, a condition which, since early Modernity, had been bracketed by the subject's self-image as a disembodied entity. If, however, the senses and sensual perception began to matter again, this implied that, as long as the world continued to be regarded "as a book", this book was - metaphorically speaking-a book whose materiality could no longer be overlooked. And yet, we all know that there was no corresponding scholarly interest in the "materialities of communication" during those 19th century decades when the second order observer became an institutionalized epistemological condition. Why did the new epistemological framework and the direction of scholarly interest not converge? I believe what explains this astonishing - although hardly ever mentioned - non-contemporaneity between the emergence of the second order observer and a lack of interest in the material

1. Niklas Luhmann, "Sthenographie", in Niklas Luhmann et al. (eds.), Beobachter. Konvergenz der Erkenntnistheorien?, Munich, Fink, 1990, p. 119-137. 
aspects of culture, was the growing importance of hermeneutics, i.e. the growing importance of the philosophical reflection on the conditions of interpretation within the academic disciplines called "the Humanities and Arts," "les sciences humaines," or "die Geisteswissenschaften." When, around 1900 and under the decisive influence of Wilhelm Dilthey, the University of Berlin began to officially conceive of the disciplines united in the "Philosophische Fakultät" as "Geisteswissenschaften," it was both understood that interpretation would be the one and only core practice for all of them and that this concentration on interpretation would exclude any attention given to material or empirical frame conditions. Thus, the Geisteswissenschaften were born under the condition of an enforced distance from the dimension of empirical objects and facts. Or, from a different perspective : the cross-disciplinary elevation and canonization of Hermeneutics extended the dominance of the paradigm of the "readable world" within the academic humanities, and it did so in a non-academic environment that had long abandoned the idea of "the world as a book."

\section{3.}

My mini-history carries a potential answer to the initial question about the reasons for the shift of fascination from "intertextuality" to "intermediality," as it has occurred during the past decades (especially in Germany). I think we can safely assume that this shift was part of a development within which Hermeneutics and the paradigm of the "readable world" lost their total control over the humanities. Now this transformation does by no means imply that interpretation has become irrelevant or obsolete altogether. On the contrary, the humanities would miss a perhaps unique opportunity of intellectual complexification if they simply tried to replace the traditionally exclusive concentration on meaning and interpretation through an equally exclusive concentration on media and materialities. Therefore, independently of the specific direction for which one decides to opt within the future conceptual development of the humanities, it is imperative to avoid any return to a monistic paradigm. In a way, the step from a monism based on the concept of meaning to a bipolarity between meaning and "materiality" is a legacy that connects us with the emergence of the second order observer. We should thus avoid two extremes: we should avoid all those

2. Hans Ulrich Gumbrecht, Production of Presence. What Meaning Cannot Convey, Stanford, Stanford University Press, 2004, p. 21-59 (forthcoming). 
media-concepts that can be subsumed under purely hermeneutic premises; but we should also avoid those other media concepts that tend to completely absorb the dimension of meaning. To give an example: in the long run, Friedrich Kittler's provocative (and quite beautiful) aphorism "there is no software" (to be translated into: "there is no meaning dimension") $)^{3}$ misses the contemporary opportunity for the humanities of reaching a higher level of complexity, and it does so as much as the traditional hermeneutic paradigm of the "world as a book." To produce and preserve intellectual complexity is the reason why we should conceive of the relation between "sense" and "materiality," between "meaning" and "media," as a relation of tension or of oscillation - and not as a relation of complementarity or as a relation of mutual exclusiveness. In my own, more recent work, I have proposed to transform this tension into the configuration of an irreducible oscillation between meaning production and production of presence, and I imply that "production of presence" refers to the physical and spatial conditions of tangibility which, knowingly or not, we develop with each object that we encounter. ${ }^{4}$ But there is no need to further pursue this proposal within our critical discussion of the concept of "intermediality."

\section{4.}

At this point, I should confess that I have yet to understand the absolute need and pertinence of the concept of "intermediality" - especially if we resist the temptation of abandoning the new paradigm of a tension between meaning and materiality in favor of a new monism. On the other hand, not to know exactly why a concept should be absolutely pertinent does not mean to condemn the use of this concept as impossible. Once a paradigm of tension between meaning and materiality (meaning and presence) is established, understood and institutionalized, I see two different levels on which the concept of "intermediality" can turn out to be more or less helpful. We may call these two levels "level of transposition" and "level of interference." "Level of transposition" would refer to the classical question of how certain motifs, meanings, or plots undergo transformations as they become articulated in different media: in books or on

3. Friedrich Kittler, "There is No Software", Stanford Literature Review, vol. 9, No. 1, Spring 1992, p. 81-90.

4. See Hans Ulrich Gumbrecht, Production of Presence: What Meaning Cannot Convey. 
the stage, in films or in TV-features. In this context, I think it would be a good idea to assume a continuity on the meaning-side (i.e. to assume-counterfactually-that one self-identical meaning remains unchanged throughout all the different media in which it becomes articulated), and to proceed to the question what different effects the different tensions between this stable meaning and different types of materiality/different media can possibly produce. The "level of interference," in contrast, would deal with those cases where the dimension of meaning is in a complex relationship with not just one but with several dimensions of materiality at the same time. Perhaps we should simply describe this difference between the "level of transposition" and the "level of interference" as a difference between different degrees of descriptive preciseness that a scholar wants to invest. For, if we only take time to look closely enough, we will find very few cases, if any, where meaning will oscillate with just one dimension of materiality. A book, for example, is not meaning and materiality but meaning and pages, characters, a cover, (very often) pictures, impressions of touch, impressions of smell, and more.

\section{5.}

Once this relatively modest configuration of ("theoretical") concepts and dimensions is established around the concept of "intermediality", I think one should abandon the expectation that it will yield sweeping results of grandiose theoretical elegance. Rather, this configuration invites for a long overdue change in intellectual style. For should the Germanico-academic fascination with media and materialities of communication ever want to transcend, finally, its - still likeable but no longer so new - state of youthful enthusiasm, it is high time to switch from an intellectual style of very general statements to a culture of patient historical and empirical research. Yes, it would be interesting to find out, for example, how our daily use of electronic mail has changed and will change our ways of writing and even of thinking. But, frustrating as this may be, convincing answers to questions of this type will not come from just playing with concepts that are as broad as those which made authors like Walter Benjamin, Gilles Deleuze, Jacques Derrida, or Giorgio Agamben famous. Rather, it will come from detailed empirical (and certainly often enough: quite cumbersome) research. Personally, I do not find the prospect of such empirical research without a prospect of philosophical redemption terribly appealing. But for those who have written the big word of "intermediality" on their banners, it seems to be the one worthwhile-and perhaps even the one legitimate- 
future that I can see. A programmatic goal for such empirical research could be to find out whether there exists any specific configuration of "intermedial" phenomena within the cultures of the Iberian peninsula and of South America (or within any other specific national, regional, or historical cultures). For while it is hard to imagine that one culture could be "more intermedial," in general, than any other culture, there is some reason to expect that certain historical periods and certain genres may have pushed certain possibilities of the intermedial dimension further than others.

\section{6.}

This said, I will insist, one final time, on what I think is the one single most important condition to keep in mind for any future work in the dimension of intermediality. It must avoid, on the phenomenal side of "media" or "materiality," any concepts that are not clearly and indeed ontologically separated from concepts of meaning. As soon as we subsume "genres," "discourses," or "cultures" under the concept of "media," we have given up the new, post-hermeneutic and post-semiotic intellectual complexity that the humanities have a chance to reach. The same is true for a widespread tendency to allow or even to indulge in easy analogies. Speaking, for example, of "filmic metaphors," means that we "read" films as if they were "texts," and once we do so, we have abandoned the one dimension of epistemological difference that can make Intermediality interesting. Rather than assuming that something like "filmic metaphors" does exist, one should ask what phenomenon, in a film, could possibly have a status of heteronomy comparable to the status of a metaphor, i.e. of a visual association overriding a conceptual structure, in a text. So what is most required, perhaps, is an active eagerness to find new problems without any guaranteed solutions, an eagerness to spot problems which would have to replace the now prevailing attitude of always acting as if easy, almost formulaic solutions were at hand. Under this condition, "intermediality" could be a (slightly pompous) word for a truly challenging intellectual future. Otherwise, without that passion for the truly unknown, it will most likely degenerate into yet another field of academic complacency. 